\title{
Implementation of Industrial Incubators to Improve Enterprise Intention in East Java Indonesia
}

\author{
Tanto Gatot Sumarsono, Sih Hanto, Suatmo Pantja Putra, Priyo Sudibyo \\ University of Merdeka Malang, Indonesia
}

\begin{abstract}
Entrepreneurship intentions among students in East Java are carried out by analyzing business incubators and local business potentials in East Java Province. Several research findings indicate that business activities that are prospective for development in the East Java region are quite diverse and are carried out by entrepreneurs in the region, while the growth of young entrepreneurs is still limited. The potential of the business sector that can be developed by young people in East Java can be a means to create young entrepreneurs. Here, there is no maximum effort to develop business activities on micro, small, or medium scale products. In addition, local governments and universities have given their role to foster entrepreneurship in community groups including young people, however, it is still not optimal. Finally, the incubator business development is carried out to develop entrepreneurial intentions among students.
\end{abstract}

\section{INTRODUCTION}

$\mathrm{T}$ his research is a form of revitalization of entrepreneurship learning about the importance of student entrepreneurship learning, so that in the future it is expected that young entrepreneurs who are able to create jobs will grow. In detail, this study will examine the role of the campus in integrating entrepreneurship learning into the curriculum, the role of the campus in shaping the character of independence and the implementation of entrepreneurship learning in the campus environment.

Based on the 2020 Labor Force Situation in Indonesia, in February 2020 the number of open unemployed D-3 graduates reached 431,421 people. In the same period in February 2021 the number rose to 454,067 people. Meanwhile, unemployment with a bachelor's degree (S-1) in February 2020 reached 1,421,217 people. In the same period the following year the number rose to $1,912,158$ people. In fact, the number of undergraduate intellectual unemployment (S-1) was quite significant in previous years. In August 2017 the number was $1,161,862$ people. Then it fell to 729,601 people in 2018 and in 2019 to 1,257,058 people. In addition to the availability of job opportunities, the pandemic period and readiness to enter the world of work are also factors that increase the number of intellectual unemployment.

Industrial Incubator Based Learning-based entrepreneurship is a new paradigm in the world of business in this country. The entrepreneurship that takes shape develops speed and flexibility. This study is different from previous research which is more directed at the entrepreneurial problems of business actors in the MSME sector, while the object of this research is Student
Entrepreneurship as a future generation who is expected to have toughness in entrepreneurship. For this reason, it is necessary to obtain the right model to realize the addition of Young Entrepreneurs.

The results of this study can be applied to the object of research, so that there is growing awareness of the importance of entrepreneurship from a young age and supported by the skills and business insights obtained in the business incubator and applications in the business environment of MSMEs in Malang Raya and Pamekasan Madura. The aim of this research is :

1. Implementation of a business incubator in fostering entrepreneurial intentions among students

2. The implementation of entrepreneurship by utilizing local potential in increasing entrepreneurial intentions

\section{LITERATURE REVIEW}

Longenecker, Moore \& Petty (2001) stated that an entrepreneur or entrepreneur is a decision maker who helps form a free corporate economic system, most of whom are drivers of change, innovation and economic progress in the future, people who have the ability to take risks. and accelerate economic growth.

An entrepreneur is not afraid of failure, he focuses his attention on future successes and uses failure as a valuable experience. An entrepreneur must be a good leader, he leads human resources with various characters and manages other resources efficiently and effectively.

Coulter (2003) emphasizes the main elements of entrepreneurship that must exist in the definition of entrepreneurship, namely: (1) the entrepreneur; (2) innovation; (3) organization creation; (4) creating value; (5) profit and non profit; (6) growth; (7) uniquess; (8) process.

The explanation of each is as follows:

(1). The entrepreneur (entrepreneur), is the first most important element in entrepreneurial activities. Entrepreneurship will not be able to run without someone who carries out his business activities to achieve the expected goals.

(2) Innovation (innovation), which includes activities to replace, revolutionize, change, and introduce new approaches. 
(3) Organization creation (forming an organization), to pursue opportunities and make innovations to produce value, entrepreneurs must organize their efforts and take action.

In creating entrepreneurs, you can combine education and entrepreneurship training. Education functions to provide materials for entrepreneurship while training is intended to hone the soft skills of prospective entrepreneurs. Through these two things, it is hoped that prospective entrepreneurs will be motivated to open new businesses, have the courage to take risks, and are not afraid of failure.

The government plays the role of mediating capital issues. Government activities focused on increasing the number of entrepreneurs through capital loans are generally called business incubators. The funding assistance is used as initial capital to set up a business. Entrepreneur candidates who dare to take risks will not be afraid to fail, because even a big entrepreneur must experience several failures to achieve success.

The scientific character of entrepreneurship is designed to know (to know), do (to do), and become (to be) an entrepreneur. The purpose of to know and to do education is integrated in the curriculum of study programs, distributed in scientific subjects. Integration is intended to internalize entrepreneurial values. In this stage, universities provide entrepreneurship education courses aimed at providing motivation and forming entrepreneurial mental attitudes. Meanwhile, the goal of becoming an entrepreneur is given in practical business skills training.

Related research outputs include research by Fristin (2012) which discusses the development of area-based rural incubators through BIG synergy in the context of creating new entrepreneurs in Malang Regency.

The need to produce young entrepreneurs is an urgent need to meet the government's target in realizing the growth of young entrepreneurs. So that the role of universities in encouraging the growth of new entrepreneurs can be realized.

Realizing technological innovation into business practices. On the other hand, systematic extra-curricular activities of students can also build motivation and mental attitudes of entrepreneurs. Coaching students as prospective entrepreneurs in various activities of interest and talent, science, welfare or other organizations is able to provide skills for entrepreneurship, in the sense of business entrepreneurship, as well as corporate (or intrapreneur) entrepreneurs.

The development of entrepreneurship education is oriented to providing entrepreneurial competence to students with the aim that the competency program includes understanding the concepts of to know, to do, and to be entrepreneur. The goal is to systematically cultivate the entrepreneurial spirit so that motivation, mentality and entrepreneurial character can be developed in a more real (empirical) competitive climate of the world of work.
Wigunadika (2021: 47) states that an entrepreneur plays a role both internally and externally. Internally, an entrepreneur plays a role in reducing the level of dependence on others, increasing self-confidence, and increasing the purchasing power of the perpetrators. Externally, an entrepreneur plays a role in providing job opportunities for job seekers. With the absorption of labor by the employment opportunities provided by an entrepreneur, the national unemployment rate is reduced. The decline in the unemployment rate has an impact on increasing per capita income and people's purchasing power, as well as the growth of the national economy. In addition, it also has an impact on decreasing the crime rate which is usually caused by high unemployment. In addition, entrepreneurs must be smart in looking for potential profits. Getting the maximum profit is closely related to the ability to read the market.

Entrepreneurs are required to be able to find a business with a lot of profit and little competition. The ability to read this opportunity will prevent entrepreneurs from risking too big a loss if their business does not grow anymore. Furthermore, entrepreneurs must be able to create a personal franchise. Looking for businesses that can be imitated from people who have had success with the business first. This kind of business will save entrepreneurs time because of the trial and error process. It is called a private franchise because there will be systems, tools, training, and guidebooks that will lead the entrepreneur to success. At this stage, entrepreneurs are required to open a network as well as learn from business people in the same field as conditions that have been successful first. Finally, entrepreneurs must build a strong business mentality. A tough businessman will always learn how to grow his assets. He will never be satisfied in seeking or asking for specific tips in building his business. He will try to maximize his assets in making money to build his financial capabilities. He will also avoid working for money.

Wibowo (2011) provides two limitations for measuring the success of entrepreneurship studies at the tertiary level. First, by measuring the amount of time and effort students are involved in the learning process. Second, the university's ability to provide resource services, curriculum, facilities and activity programs that attract student participation to increase actualization, satisfaction and entrepreneurial skills. Referring to a number of theories and the results of empirical studies, measures of the success of entrepreneurship learning at the tertiary level can be grouped into process dimensions and outcome dimensions.

H1 Produces the implementation of an industrial incubator

H2 Generates utilization of local potential to increase entrepreneurial intentions among students.

\section{RESEARCH METHODS}

This study seeks to apply an industrial incubator model that suits students' interests to choose business fields according to regional potential in Malang Raya and Pamekasan. The second stage is to distribute questionnaires to 
150 students from Merdeka University Malang, Raden Rahmat Malang University, STIKes WCH Malang and Madura Pamekasan University. Followed by a focus group discussion. Students are divided into groups of young entrepreneurs who have chosen a business field consisting of handicrafts, services, trade and agribusiness. This choice is in accordance with the local potential available in Malang Raya and Pamekasan. Furthermore, to test the model for the creation of young entrepreneurs in business locations in Malang Raya and Pamekasan.

The method of analysis uses a mix method, which combines descriptive qualitative analysis and quantitative analysis. Descriptive qualitative analysis is used to explain the perceptions of the respondents through a questionnaire. Quantitative analysis uses PLS-SEM analysis to produce the influence between industry incubator variables, local potential and entrepreneurial intentions.

Statistical analysis using inferential statistics to test the strength of each indicator in forming variables, so that it can be seen which indicators are dominant in forming variables, by knowing the value of the factor loading of each indicator on the variable. In addition, it will also be known the influence between the independent variable and the dependent variable. The analysis used in this study used PLS-SEM (Partial Least Square - Structural Equation Modeling)

\section{RESULTS AND DISCUSSION}

Reliability test is used to measure the consistency of the constructs / research variables.

A variable is said to be reliable (reliable) if the respondent's answer to the question is consistent or stable over time. A reliable instrument means that when used several times to measure the same object, it will produce the same power (Sugiyono and Susanto, 2015). The level of reliability of a research construct / variable can be seen from the results of the Cronbach alpha $(\alpha)$ statistic. A variable is said to be reliable if it provides a Cronbach alpha value greater than 0.60
(Ghozali, 2014). The results of reliability calculations by SPSS can be seen in the following table:

Table 1. Reliability and Validity

\begin{tabular}{|c|c|c|c|c|}
\hline & $\begin{array}{c}\text { Cronbach's } \\
\text { Alpha }\end{array}$ & rho_A & $\begin{array}{c}\text { Composite } \\
\text { Rel }\end{array}$ & AVE \\
\hline $\begin{array}{c}\text { Enterprise } \\
\text { Intention }\end{array}$ & 0,794 & 0,083 & 0,857 & 0,546 \\
\hline $\begin{array}{c}\text { Industrial } \\
\text { Incubators }\end{array}$ & 0,798 & 0,803 & 0,861 & 0,553 \\
\hline Local Potential & 1,000 & 1,000 & 1,000 & 1,000 \\
\hline
\end{tabular}

Based on the results of the calculation of the value of Cronbach's Alpha $(\alpha)$ and Composite Reliability, all variables are greater than 0.70 which means that all questions used in the study are reliable. Meanwhile, the validity based on Gozali (2014) convergent validity can be seen from the AVE output. A construct is said to have a good convergent validity if the AVE value exceeds 0.50. The AVE output value of all constructs is greater than 0.50 means that all constructs have good convergent validity.

Based on the Cross Loading table, it shows that all the indicators that make up each variable in this study meet discriminant validity, namely with a cross loading value greater than 0.7 (Hartono, 2011).

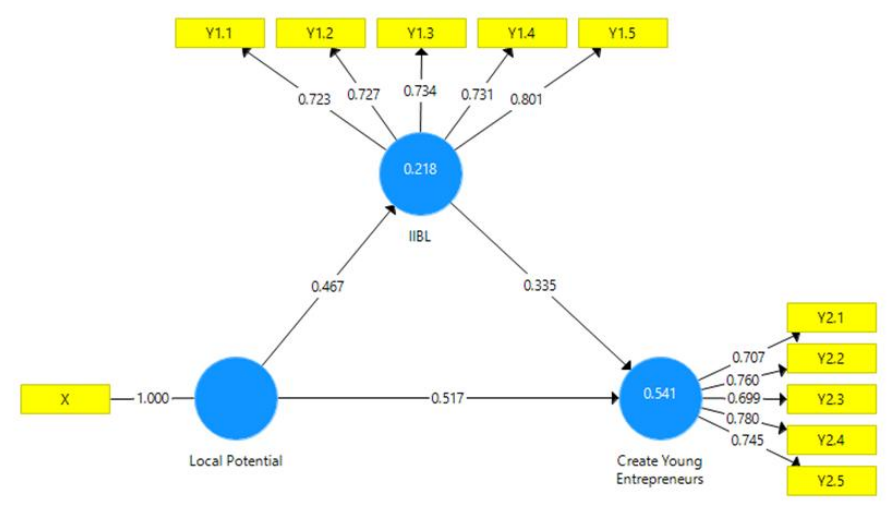

Table 2 Outer Loading

\begin{tabular}{|c|c|c|c|c|c|}
\hline & $\begin{array}{c}\text { Original } \\
\text { Sample }\end{array}$ & Sample Mean & SD & $\mathrm{T}$ & $P$ values \\
\hline$X<---$ Potensi Lokal & 1,000 & 1,000 & 1,000 & & \\
\hline Y1.1 <--- Industrial Incubators & 0,723 & 0,725 & 0,050 & 14,415 & 0,000 \\
\hline Y1.2<--- Industrial Incubators & 0,727 & 0,724 & 0,057 & 12,759 & 0,000 \\
\hline Y1.3<--- Industrial Incubators & 0,734 & 0,734 & 0,060 & 12,262 & 0,000 \\
\hline Y1.4<--- Industrial incubators & 0,731 & 0,729 & 0,056 & 13,058 & 0,000 \\
\hline Y1.5 < --- Industrial Incubators & 0,801 & 0,799 & 0,046 & 17,366 & 0,000 \\
\hline Y $2.1<---$ Enterprise Intentions & 0,707 & 0,703 & 0,085 & 8,298 & 0,000 \\
\hline Y $2.2<$ Enterprise Intentions & 0,760 & 0,762 & 0,045 & 16,804 & 0,000 \\
\hline Y $2.3<---$ Enterprise Intentions & 0,699 & 0,694 & 0,063 & 11,027 & 0,000 \\
\hline Y $2.4<---$ Enterprise Intentions & 0,780 & 0,765 & 0,062 & 12,523 & 0,000 \\
\hline Y $2.5<---$ Enterprise intentions & 0,745 & 0,739 & 0,061 & 12,189 & 0,000 \\
\hline
\end{tabular}


Based on the outer loadings score above, it can be seen that all indicators can be declared valid and statistically significant in measuring their respective constructs. Because the loading value $(\lambda)$ of all indicators is more than 0.50 with a statistical $t$ value of more than 1.96 .

The outer model is not only measured by assessing the convergent validity and discriminant validity, but also by looking at the reliability of the construct or latent variables which are measured in two ways, namely by looking at the composite reliability value and Cronbach alpha from the indicator block measuring the construct. The construct is declared reliable if the composite reliability value and Cronbach alpha value are greater than 0.70 (Latan \& Ghozali, 2012).

According to Chin (1998), the value of R2 is considered weak, moderate, and strong if it shows respectively around $0.19,0.33$, and 0.67 (Ghozali, 2014). In this research model, there is one variable that is classified as moderate industrial incubator because it approaches the value of 0.33 and one variable that is classified as strong because it approaches the value of 0.67 . This coefficient of determination states that the R2 value of the endogenous latent variable Business Incubator and Entrepreneurial Intention has an R2 value of 0.218 and 0.541 which indicates that as much as $21.8 \%$ of IIBL data variation and $54.1 \%$ of entrepreneurial intention data variation is influenced by local potential.

Table 3. R Square

\begin{tabular}{|l|c|c|}
\hline & R Square & R Square Adjusted \\
\hline Enterprise Intentions & 0,541 & 0,531 \\
\hline Industrial Incubators & 0,218 & 0,210 \\
\hline
\end{tabular}

Tabel 4. Path Analysis

Path Coeficients

\begin{tabular}{|c|c|c|c|c|c|}
\hline & $\begin{array}{c}\text { Origi } \\
\text { nal } \\
\text { Sam } \\
\text { ple }\end{array}$ & $\begin{array}{c}\text { Sampl } \\
\mathrm{e} \\
\text { Mean }\end{array}$ & SD & T stats & P value \\
\hline $\begin{array}{c}\text { Industrial } \\
\text { Incubators -> } \\
\text { Enterprises } \\
\text { Intentions }\end{array}$ & $\begin{array}{c}0,33 \\
5\end{array}$ & 0,340 & 0,077 & 4,337 & 0,000 \\
\hline $\begin{array}{c}\text { Local Potential } \\
\text {-> Enterprise } \\
\text { Intentions }\end{array}$ & $\begin{array}{c}0,51 \\
7\end{array}$ & 0,522 & 0,062 & 8,334 & 0,000 \\
\hline $\begin{array}{c}\text { Local Potential } \\
\text { - Industrial } \\
\text { Incubators }\end{array}$ & $\begin{array}{c}0,46 \\
7\end{array}$ & 0,479 & 0,077 & 6,080 & 0,000 \\
\hline
\end{tabular}

In the results of data analysis using Smart PLS 2.0 as in the Path analysis table 4 show that the coefficient of the local potential to entrepreneurial intention is 0.517 , local potential to industrial incubator is 0.467 , and industrial incubator to entrepreneurial intention is 0.335 . Thus the indirect effect has a smaller path coefficient, namely 0.156 (0.467x 0.335) compared to the direct path coefficient of 0.517 . This path coefficient proves that local potential has a smaller indirect effect on entrepreneurial intentions than the direct effect of local potential on entrepreneurial intentions.

This study involved 150 respondents who have an interest in becoming entrepreneurs. As well as representatives of the entrepreneur community as many as 8 people with Handicraft, Agribusiness, Services and Trade activities. The Focus Group Discussion (FGD) results show that the creation of entrepreneurs with indicators of innovation, independence, creativity and leadership are also elements that influence the success of entrepreneurs in these various fields. Based on these characteristics, there are at least two groups of entrepreneurs who can encourage the creation of young entrepreneurs among students, namely the spirit of innovation who is aggressive and skilled in making changes and breakthroughs in starting a business. Besides that, there is also innovation in studying the success of others by imitating and running their business.

The implementation of industrial incubators among students is to foster entrepreneurial intentions. This step is taken by making a business proposal according to the group's interest in the business incubator, then the group can look for business partners that are relevant to their business. The results obtained show that most of the businesses are in the food sector. Then followed by businesses in the field of services, crafts and agribusiness. When the desire for entrepreneurship appears, the next step is to strengthen the participants or the classes that are prepared by bringing up entrepreneurs to strengthen business knowledge. Business knowledge in the form of basic functions, both aspects of finance, marketing or human resource management can be given practically, in addition to business strategies and analysis of the business environment and business ethics.

From here it is hoped that a process of transfer of knowledge and business practices will occur from the owner to the apprentice. In the future, the company where the apprenticeship can become a kind of foster parent or even partner with newly educated entrepreneurs. If this process goes well, it is hoped that it will further encourage apprentices to jump right into the business world. When participants complete their internships, these participants can set up their new business.

In this phase, of course, problems will arise, this condition is a critical condition, because at this stage these young entrepreneurs are really being tested, whether they are still able to become entrepreneurs. Furthermore, in this critical phase, assistance is needed. Here the role of universities in developing entrepreneurship for business assistance and consulting. The companies where the apprenticeship (partners) can also play a role in it to help provide assistance.

The next phase is to emerge independent entrepreneurship. In this phase, the companion agency views that young entrepreneurs are capable of being independent, so it can be said that this phase of young entrepreneurs can be released. In this phase, the company is able to pass on its knowledge and become foster parents for new apprentices and 
entrepreneurs. It has started to spend its Corporate Social Responsibility (CSR) funds to contribute to developing young entrepreneurs. If this is done consistently and there is concern for both the community and the government, it will encourage the emergence of young entrepreneurs from among students in large numbers.

\section{CONCLUSION}

The implementation of the industrial incubator can use a programmatic model of entrepreneurship creation. To use the creation model, it is necessary to have parties who take part in bringing forth young entrepreneurs. The model of growing the spirit and spirit of entrepreneurship, apprenticeship and encouraging someone to become an entrepreneur so that he is truly independent will accelerate the emergence of many new entrepreneurs, so that it is hoped that it can eradicate unemployment and poverty.

The implementation of a business incubator among students is very much determined by the local potential in the location of the student, because the support of the incubator and the business world is easier to obtain, where in the Greater Malang area business incubators can be developed in the fields of crafts, agribusiness, services and trade. Meanwhile, in the Pamekasan area, there are more trade and agribusiness businesses.

The creation of young entrepreneurs through students should be supported by the government and the private sector in encouraging the realization of young entrepreneurs from higher education institutions, so that the role of universities can be supported by government programs and involving the private sector.

\section{REFERENCE}

[1] Aghajani, H., \& Abbasqholipour, M. 2012. Explanation of Relationships between Biographical Characteristics and Entrepreneurship Spirit of Students. Iranian Journal of Management Studies (IJMS). Vol 5, No. 1, January 2012. Pp. 6378.

[2] Chin, W.W., 1998 The partial least squares approach for structural equation modeling. in G. A. Marcoulides (Ed.), Modern methods for business research (pp. 295-236). London: Lawrence Erlbaum Associates.

[3] Coulter, M., 2003, Entrepreneurship in Action, New Jersey: Prentice Hall.

[4] Farida., Eka, Ery Tri Djatmika, Bambang Banu Siswoyo, Mit Witjaksono, 2017, Development of a Project-Based Entrepreneurship Learning Model to foster the Entrepreneurial Spirit of Students in the Economics Education Study Program of IKIP PGRI Bojonegoro, JPEK, Volume 1, Number 1, July 2017, page 8 - 18

[5] Fristin, Yunta, 2012, Development of an Area-Based Rural Incubator Model Through BIG Synergy in the Framework of Creating New Entrepreneurs in Malang Regency. Research Report.

[6] Ghozali, Imam. 2014. Structural Equation Modeling, Alternative Methods with Partial Least Square (PLS). 4.Semarang Edition: Diponegoro University Publishing Agency.

[7] Hartono, Jogiyanto. (2011). Business Research Methodology: Misunderstandings and Experiences. BPFE. Yogyakarta.

[8] Indonesian Central Bureau of Statistics, 2017, State of the Labor Force in Indonesia, August 2017
[9] Indonesian Central Statistics Agency, 2018, State of the Labor Force in Indonesia, August 2018

[10] Indonesian Central Bureau of Statistics, 2019, State of the Labor Force in Indonesia, August 2019

[11] Indonesian Central Bureau of Statistics, 2020, State of the Labor Force in Indonesia, February 2020

[12] Indonesian Central Statistics Agency, 2021, The State of the Labor Force in Indonesia, February 2021

[13] Latan, H., \& Ghozali, I. (2012). Partial Least Squares Concepts, Techniques and Applications using the SmartPLS 2.0 M3 Program. Diponegoro University Publishing Agency: Semarang

[14] Longenecker, J.G., CW. Moore and JW.Petty, 2001, Entrepreneurship: Small Business Management, Book 1 (Thomson Leaning Asia Translation), Jakarta: Salemba Empat

[15] Sarjono, et al. 2012. Evaluation Results of Entrepreneurship Study Program. IKIP, Bojonegoro. Not Published.

[16] Wibowo., 2011. Work management. Third Edition. Jakarta: PT Raja Grafindo Persada.

[17] Wigunadika, I Wayan Sapta, 2021, Fostering Interest of the Young Generation to Become Entrepreneurs, Nilacakra Publisher, Bali 